\title{
The Impact of Socio-Historical Context on Identity: An Analysis of Ngāi Tamarāwaho Identity in the Colonisation Era
}

\section{Introduction}

The purpose of this article is to illustrate the influence that socio-historical context has on the identity of a group. The identity of the hapū (tribe) Ngāi Tamarāwaho is examined to demonstrate the impact that specific phenomena associated with colonisation had on hapu identity, and the major focus of this chapter is the interplay between Ngāi Tamarāwaho and the phenomenon of colonisation. This article concentrates specifically on hapū identity during the colonisation era, which, in the context of this article, commenced with the arrival of Pākehā (British) settlers in New Zealand in 1814, and concluded with the establishment of the Waitangi Tribunal in 1975. For comparative purposes, parallels are drawn with other indigenous groups globally to highlight similarities between the colonisation experiences of these groups and those of Ngāi Tamarāwaho, and to illustrate common trends that occur as a result of colonisation and its associated phenomena. The first section in this article discusses the need to consider socio-historical context in research pertaining to identity, and provides examples of research that has been conducted to this effect. The second section establishes the social context of Ngāi Tamarāwaho, and the third section outlines the historical context. Following this is an analyis of the effects of aspects of colonisation on Ngāi Tamarāwaho 
identity, and this article concludes by discussing ways in which the hapu revived and reasserted their identity

\section{IDENTITY AND SOCIO-HISTORICAL CONTEXT}

Inherent in this discussion is the notion that socio-historical context influences identity, and Strauss $(1959,1994)$ argues that in order to understand identity and behaviour, the sociohistorical context must also be considered. Furthermore, Strauss (1959) suggests that examining a generation and the common socio-historical experiences they share will reveal that members of that generation have similar identities and behavioural tendencies. Therefore, by identifying the shared commonalities and the social processes from which they derive, the impact of socio-historical context on identity can be addressed (Labov \& Waletzky, 1967; Strauss, 1959, 1994). Researchers compared different generations within an ethnic group to highlight the influence of socio-historical contexts on identity. Korgen (1998), Schulz (1998) and Houkamau (2006) conducted intergenerational studies on bi-racial Americans (individuals with both an African American and a white American parent), Navajo women, and Māori women, respectively, to highlight the relationship between sociohistorical contexts and identity. The researchers compared different generations within these ethnic groups and contextualised the responses by considering the sociohistorical settings in which the research participants were raised.

The findings in all three studies demonstrate how social and political changes, in particular, shaped the identities of members of these ethnic groups. For example, Navajo women born when tribal members were still raised in traditional communities speaking their native language acknowledged their tribal affiliations, and stressed the importance of their language and culture in defining their identity. Women born a 
generation later when Native American leaders were resisting government policies to eradicate tribal communities by promoting a pan-tribal 'Indian' identity were more likely to define themselves as 'Indian' and espouse the benefits of unity between the tribes, while the youngest participants, born when the Navajo culture and language was undergoing a renaissance, were bicultural, bilingual and politically aware (Schulz, 1998). Similarly, in Korgen's (1998) study on bi-racial Americans, the impact of the political changes that took place due to the Civil Rights Movement can be witnessed in the identities of the three generations of participants. Houkamau (2006) examined three socio-historical processes and their impact on the identities of three generations of Māori women. Her research shows that social contexts influenced by phenomena such as urbanisation, assimilation, and political and cultural renaissance impacted on the participants' identity. All three studies validate the impact of sociohistorical conditions on identity and, consequently, stress the need for future research to consider such conditions and the influence they may have. The remaining sections of this article examine the socio-historical context of the colonisation era in New Zealand, and the impact the phenomena evident in this era had on the identity of Ngāi Tamarāwaho.

\section{THE SOCIAL CONTEXT}

Ko Tākitimu te waka

Ko Mauao, ko Puwhenua ngā maunga

Ko Te Awanui te moana

Ko Kopurererua te awa

Ko Ngāti Ranginui te iwi

Ko Ngāi Tamarāwaho te hapū

Tākitimu is the canoe

Mauao and Puwhenua are the mountains 
Te Awanui is the sea

Kopurererua is the river

Ngāti Ranginui is the extended tribe

Ngāi Tamarāwaho is the tribe

Ngāi Tamarāwaho is a hapū of the Tauranga iwi (extended tribe), Ngāti Ranginui. They are descendants of the captain of the Tākitimu waka (canoe), Tamatea Arikinui, who is known by many names. To Ngāi Tamarāwaho, he is Tamateapokaiwhenua. The hapū name comes from their ancestor, Kinotaraia, who was the grandson of Tamateapokaiwhenua and son of Kinonui, the great chief of Mauao. After Kinonui was killed at the Battle of Te Kokowai on Mauao, Kinotaraia was given the name Tamarāwaho, the Son of the Sea Breeze, when he moved inland and settled the area 'touched by the breeze' that blows from Mauao to Puwhenua (Riseborough, 1999).

Since the arrival of the Tākitimu in Tauranga, Ngāi Tamarāwaho has occupied their ancestral lands, which lie between the Waimapu and Wairoa Rivers, go as far inland as Te Rì o Tamarāwaho in the Mangorewa Gorge and extend beyond Te Papa out to sea. The map below (see Fig. 1) illustrates the tribal area of Ngāi Tamarāwaho and the neigbouring hapū, with whom Ngāi Tamarāwaho had close interactions. 


\section{NGAI TAMARAWAHO ROHE MAP}
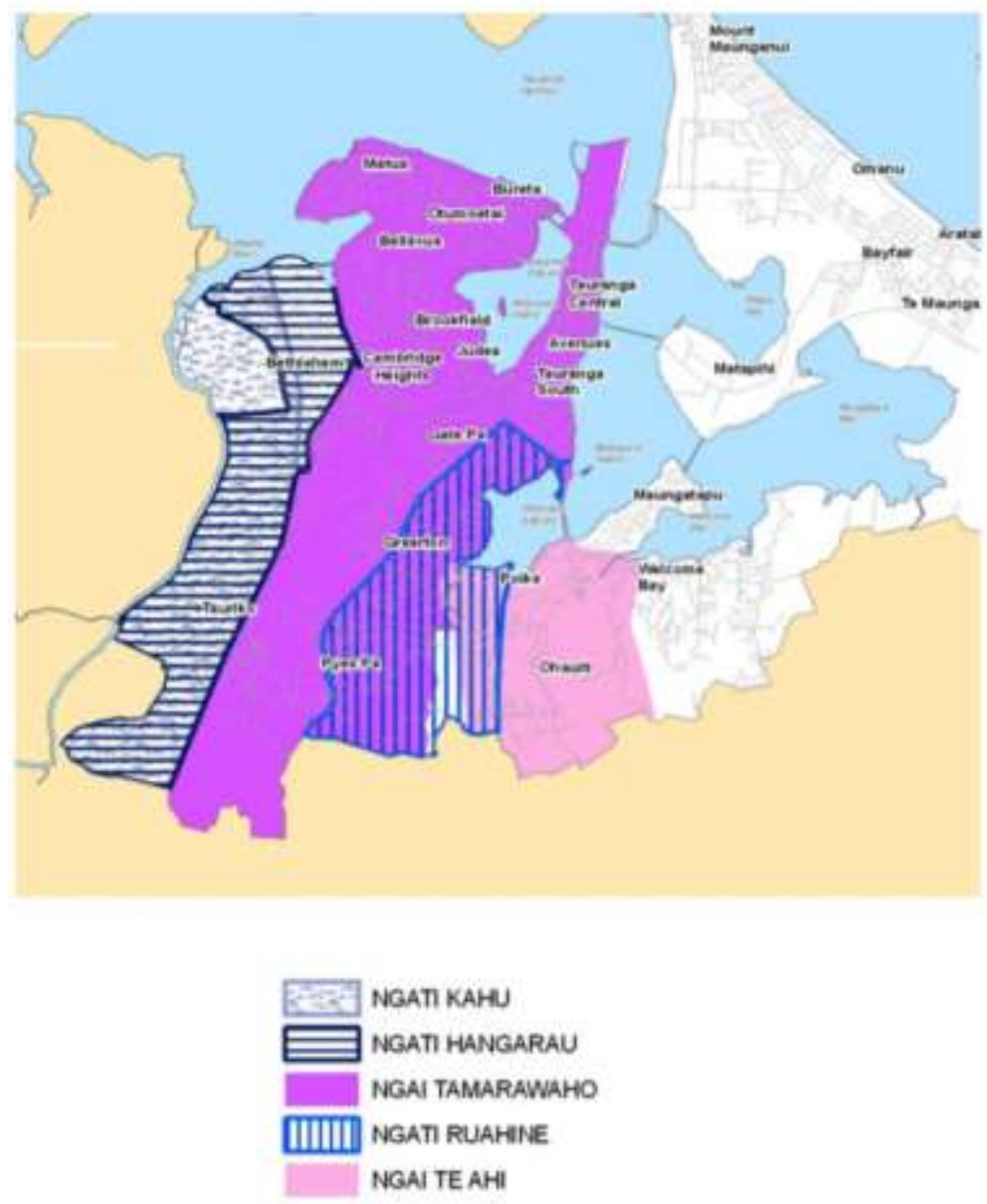

Figure 1. The tribal area of Ngāi Tamarāwaho, and the positions of neighbouring hapū (source: Mikaere, B. (2015). Te Mana o Ngāi Tamarāwaho Incorporated). 


\section{THE HISTORICAL CONTEXT}

This section focuses on two aspects associated with the Ngāi Tamarāwaho relationship with colonisation; specifically interactions between the hapu and the Church Missionary Society (CMS), and military conflict between the hapu and the Crown. The constraints of this article do not allow for a more detailed account and analysis of every phenomenon associated with colonisation, but what is shown by the content provided is that the interactions between the CMS and the Crown impacted on the socio-economic profile of Ngāi Tamarāwaho, which consequently affected the identity of the hapū. The social phenomena present in this era influenced the identity of the hapū, thus illustrating the impact of socio-historical context on identity.

Central to the policy of colonialism, which informs the process of colonisation, is the notion of cultural supremacy (Thiong'o, 1986; Trask, 1999), and the introduction of Christianity to indigenous communities worldwide resulted in many indigenous groups forsaking their own traditions and behaviours for those of the colonisers (Trask, 1999). In New Zealand, Ka'ai-Oldman (1988) notes, 'The missionaries saw themselves as the instrument by which the Maori people would be brought from the state of barbarism to civilised life' (p. 22). Similarly, Binney (1968) discusses the aim of the missionaries and their intentions 'specifically to transform, indeed eradicate, by their actions and words, the existing structure of Māori society' (p. 13). Walker (1990) concurs and describes the missionaries as 'the cutting edge of colonisation' (p. 85), who arrived in New Zealand with ethnocentric attitudes of racial and cultural superiority (Ward, 1995).

In 1834, Reverends William Williams and Alfred Nesbit Brown arrived in Tauranga with the explicit aim of choosing a site for their mission station (Riseborough, 1999). Due to ongoing skirmishes with various tribal groups in the 1820 s and early 1830s, a permanent missionary presence was 
welcomed by Ngāi Tamarāwaho (O'Malley, 1996). Therefore, hapū leaders agreed to the CMS establishing a mission station on Te Papa peninsula, believing the missionaries' presence would bring education to the hapu and stability during an unsettled period (Wainwright \& Feint, 2000). Missionary records of this time indicate there was great interest shown by many hapū members in learning to read and write (Woller, 2011). However, the relationship between Ngāi Tamarāwaho and the CMS began to detoriate when, in October 1838, the CMS announced that it had purchased the site of the mission station, with a further 1333 acres reported to have been purchased in 1839. With this additional purchase, the station covered virtually the whole of Te Papa back as far as Pukehinahina, which was a significant portion of Ngāi Tamarāwaho land (Riseborough, 1999). Payment for the block comprised goods valued at approximately $£ 100$ (Stokes, 1990). The loss of the valuable land with its rich soil and strategic location resulted in economic hardship for Ngāi Tamarāwaho, the details of which are discussed later in this article.

Ngāi Tamarāwaho's relationship with the Crown was severely damaged when Crown troops landed in Tauranga in January 1864, ostensibly to 'stop the road to the Waikato' during the New Zealand Wars (Wainwright \& Feint, 2000, p. 14). However, General Cameron and his troops did not arrive in Tauranga until after the end of the war in Waikato, and Crown moves were seen as purely provocative and designed to elicit an aggressive response from local tribal groups. On 29 April 1864, Crown troops attacked Ngāi Tamarāwaho and other hapū at Pukehinahina, commonly known as Gate Pā, and between 220 and 240 Māori warriors defeated over 1650 Crown troops (Mair \& Gifford, 1937). Following this battle, Ngāi Tamarāwaho, with other tribal groups, began to entrench themselves further inland from Pukehinahina at Te Ranga which, like Pukehinahina, is also in Ngāi Tamarāwaho territory. Te Ranga, however, was an incomplete defensive position still under construction when, on 21 June 1864, it 
was attacked by Crown troops. Ngāi Tamarāwaho and other tribal groups were defeated and Ngāi Tamarāwaho fled further inland to the bush area at Taumata with hapu leader, Wi Paraone Rauhea Koikoi (Tai ${ }^{1}$, as cited in Derby, 2016). As punishment for their perceived rebellion the chief Paraone Koikoi [was] brought from the bush to witness the confiscation of his lands from the town of Tauranga to Mangorewa, some fifty odd thousand acres' (Winiata, 2000, p. 8). On 18 May 1865, the entire Tauranga district was confiscated by Order in Council under the New Zealand Settlements Act 1863 and, after questions arose over the validity of the order, the Tauranga District Lands Act 1867 was passed retrospectively to validate the confiscation of the land (Wainwright $\&$ Feint, 2000). The land loss following the New Zealand Wars plunged the hapu further into poverty, which consequently affected the identity of the hapū. Attention is given to this later in the article.

Trask (1999) observes that most indigenous groups refer to themselves as 'people of the land', and they gain 'a sense of identity [through] an attachment to place... and the natural world' (p. 104). Various researchers note the centrality of connection to tribal lands and places to Māori identity (McCormack, 2011; Mikaere, 2011; Moeke-Pickering, 1996; Panelli et al, 2008; Pere, 1988; Walker, 1989; Ward, 1999). After the confiscations, the Crown insisted on dealing with one iwi in Tauranga, that being Ngāi Te Rangi. Ngāti Ranginui as an iwi, along with the constituent hapu groups, was effectively legislated out of existence (Kahu, as cited in Derby, 2016). Trask (1999) comments on the profound impact legal definitions of identity have on indigenous peoples, where 'state powers attempt to decrease [their] numbers and therefore [their] claims by merely defining [them] out of existence' (p. 104). It took nearly a century before Ngāi Tamarāwaho was recognised as a hapū in its own right.

${ }^{1}$ Pseudonyms used 
Ngāi Tamarāwaho had some land later returned to them, which comprised 142 acres of coastal land, approximately half of which was swamp, and 6428 acre of low quality, hilly land that was a rich source of timber but not ideal for growing food. The lands returned to Ngāi Tamarāwaho were extremely inadequate, meagre in quantity, poor in quality and inconveniently situated at either end of their original tribal estate. In pre-colonial times, the hapu moved around their lands from the coast to the inland gardens to the forests at Taumata according to their needs in different seasons (Ngatoko, 2000). Evans (1997) argues land confiscations destroyed the way of life for the hapū. By the mid 1890s, Ngāi Tamarāwaho was rendered virtually landless. The experience of Ngāi Tamarāwaho bears remarkable similarities to those of indigenous peoples worldwide, where indigenous groups were confined to meagre remnants of their traditional tribal estates. The effects of this were disastrous and reduced indigenous peoples, including Ngāi Tamarāwaho, to a grim socio-economic profile (Alfred, 2009; Moreton-Robinson, 2003; Trask, 1999).

\section{COLONISATION AND NGĀI TAMARĀWAHO IDENTITY}

\section{Migration and the search for work}

Alfred (2009) notes that the displacement of indigenous peoples from ancestral lands greatly affected their ability to prosper and lead healthy lives. Indeed, the loss of their land and their economic base effectively destroyed Ngāi Tamarāwaho's ability to prosper, and this created an outmigration that severely affected their traditional hapū roles and the overall group structure. Many members of Ngāi Tamarāwaho sought work away from home in an attempt to adequately provide for their whānau. James Pope, an inspector of Native Schools, reported in 1891: 
The land they possess at Huria is little in quantity and poor in quality.... These Natives lead a miserable existence... at Huria, endeavouring to get some return from their ungrateful glebe, or working precariously for neighbouring Europeans; and when this fails, retiring inland and working in the bush, or wearing out their constitutions in the gum fields (as cited in Wainwright \& Feint, 2000, p. 56).

Indeed, the 1901 census recorded hapu members absent at gumfields and other such localities that offered them shortterm employment. This migration involved either moving the whole whānau out of the wider hapu to the area of employment, or leaving whānau to manage without their ablebodied labourers. Wainwright \& Feint (2000) comment, 'The loss of land forced Ngāi Tamarāwaho to move away... to find work to survive. This accelerated the fragmentation of the hapu and the erosion of traditional leadership and social organisation' (p. 52). Trask (1999) notes a similar trend for Native Hawaiians, who left the Hawaiian Islands for the United States of America in search of work. Similarly, Alfred (2009) comments on the meagre pockets of ancestral land left to Canada's First Nations people, which resulted in an urban drift. Consequently, a contemporary feature of indigenous populations worldwide is a population that is diasporic in nature. Furthermore, the migration of predominantly the male members of the hapu to other areas in search of work meant traditional social and cultural obligations were often unable to be fulfilled, which further affected the overall functioning of the group. Similarly, Alfred (2009) notes the effect of the migration trend on Canada's First Nations people, where the breakdown of social structures resulted in discord among their communities due to an inability to fulfil traditional social and cultural obligations. 
The trend to move to other areas to find work continued throughout the $20^{\text {th }}$ century and this 'undermined the concept of whānau' (Wainwright \& Feint, 2000, p. 52). Traditionally, whānau groups consisted of extended families and comprised 30 members or more, but the emergence of the nuclear family changed traditional concepts of whānau. Moreover, colonisation and, specifically, the alienation of tribal lands, facilitated the destruction of customary tenure that eroded traditional leadership structures and social organisation, which resulted in a loss of group cohesion for the hapu (Wainwright \& Feint, 2000). This trend was similar for other indigenous peoples, where the breakdown of social structures resulted in discord among communities (Alfred, 2009). The loss of land undermined Ngāi Tamarāwaho's ability to exercise their rangatiratanga (autonomy). Without land, a rangatira (chief) has no territory over which to exercise his rangatiratanga so he lacks the means to support his people and is unable to demonstrate attributes of leadership that brought mana (status) to the hapū. Matthews (2000) explains, 'Our people have always maintained that for a person to be of standing... you must have land.... If you have land you are somebody, if not, you are nobody' (as cited in Wainwright \& Feint, 2000, p. 51). Ngatoko (2000) adds that 'Land loss devastated our people. What I can't explain is what this did to our wairua (spirit). Our wairua has never recovered.' Butcher (2012) argues that ancestral lands have a special place in indigenous cultures and are deeply intertwined in the identity of indigenous groups. Moreton-Robinson (2003) suggests that land alienation affected the spiritual wellbeing of indigenous groups and this was evident in Ngāi Tamarāwaho.

Ngatoko (2000) also believes the economic impact of the land confiscations on his family has been devastating, and observes:

Of my eleven children... all [five] of my boys live in Australia. [They moved] in the late 60s and 70s 
because of the lack of opportunities here in Tauranga.... I had no incentives to offer them to stay, like land to build homes for their families... (p. 14).

Kahu (as cited in Derby, 2016) concurs, 'I saw some of our families who moved overseas in my generation... or to Tokoroa to the mill. Others went to Auckland or Wellington... and many never came back.' Migratory trends such as these often severed connections to ancestral lands, undermined traditional social structures, and created a diasporic population that may lead to hybrid or multiple identities for some members of the hapū.

\section{Housing and basic amenities}

Concomitant with the dire economic situation the hapu was faced with after the loss of their tribal lands was poor housing and a lack of basic amenities. Wainwright $\&$ Feint (2000) argue that the standard of housing at Huria was significantly below that of the general population for most of the $20^{\text {th }}$ century. Roimata (as cited in Derby, 2016) describes the housing at Huria during her childhood in the 1930s. 'It was terrible really. The old people were still living in raupō houses. It's hard to believe that now.' Raupō is a plant that grows in the swamp and the reeds were used to clad and line the frame of a house. Tai (as cited in Derby, 2016) describes his mother's shock at the housing conditions at Huria when she married into the hapu in the 1940s. Eight adults and seven children shared a two-room house. There were holes in the walls and it leaked when it rained. Kahu (as cited in Derby, 2016), who returned to Tauranga in 1959, lived in a house that had no back wall; the back wall was a macro carpa hedge.... I wondered why are we living like this and they're [Pākehā] living like that? Then you start to find out it's the raupatu (confiscation).' Theorists who research the effects of colonisation on indigenous peoples 


\section{The Impact of Socio-Historical Context on Identity: \\ An Analysis of Ngāi Tamarāwaho Identity \\ in the Colonisation Era}

cite poor standards of housing as a direct result of colonisation (Alfred, 2009; Trask, 1999). Indeed, a 1955 investigation into housing at Huria revealed that almost every house was sub-standard (Nightingale, 1996). In 1960, the Department of Māori Affairs estimated that 20 whānau (family) at Huria, and 25 whānau at Te Rēti, a nearby hapū settlement, needed re-housing.

Long after the provision of reticulated water, paved roads and electricity were enjoyed by the general population, Ngāi Tamarāwaho continued to live in a state of poverty and deprivation. The creek was the only water supply. In 1917, a scheme was proposed to provide a water supply to Huria at the high cost of £300. An inquiry into the conditions at Huria showed Ngāi Tamarāwaho was 'easily the poorest natives in the District' and 'not in a position to contribute at all to the cost of a water supply' (Rose, 1997). The Tauranga County Council, concerned about the difficulty they may have in collecting water rates (Riseborough, 1999), did not proceed with the scheme. By the mid-1920s, the Tauranga County Council had reticulated water to within fifteen chains of Huria but remained reluctant to extend it for the use of the hapu The Tauranga Māori Council then stepped in and provided £75 towards the cost of having a bore sunk and, with a further $£ 75$ from the Māori Purposes Fund, the project went ahead. However, it was later found that the supply was contaminated (Nightingale, 1996; Rose, 1997). It was not until the second half of the $20^{\text {th }}$ century that Huria had running water, and that came from one tap that serviced the whole community (Wainwright \& Feint, 2000).

In the 1930s, the hapu at Huria had no road, electricity, heating, or drainage, and they made their ablutions in the creek (Riseborough, 1999). Winiata (2000) recalls that in the 1940s 'no-one had a telephone or water... electricity, heating, or drainage.... There were no convenient amenities for the people of Huria....' (p. 10). The lack of heating in the houses meant hapū members were advised by medical professionals 
not to bathe their children every day. As a result of the cold and overcrowded conditions, members of the hapu suffered from 'all kinds of health complaints - bronchitis, pneumonia, tuberculosis, and convulsions...' (Tata, 2000). Alfred (2009) notes a virtually identical trend for Canada's First Nations people, where overcrowding, lack of access to clean water and poor sanitation contributed to extremely high rates of infectious disease. He cites colonisation as the cause of this trend.

\section{Health and education}

Indeed, the inevitable effects of sub-standard housing, overcrowding and a lack of modern amenities on Ngāi Tamarāwaho, was poor health, and that went hand in hand with poor educational outcomes for the hapū. Theorists examining ethnic identity find the more positively an ethnic group is perceived by society, the more positively members of that ethnic group will view their identity, and the more they will value their membership of that group (Blash \& Unger, 1995; Lee, 1997; Phinney, 1993). Conversely, if a group is stigmatised, members are prone to developing negative identity associations (Tajfel \& Turner, 1986). This often leads to disassociation with that particular ethnic group. Due to the harsh realities of trying to survive in the emerging cash economy, Ngāi Tamarāwaho decided that part of their future survival was dependent on acquiring increased access to Pākehā knowledge (Woller, 2011). This belief was evident in indigenous groups globally, and Kirmayer and Valaskakis (2009) state: 'That is the essence of life in the colony: assimilate and be like us or suffer the consequences' (p. xi). In 1883, a school was opened at Huria and hapū members requested a Pākehā teacher so that their children could learn to read and write in English (Woller, 2011). In a memo to the Department of Education, a local government official described the school established by the hapū: 
A daily school has been started [at Huria] and when I visited it yesterday 20 children were present. [They have] given up a good-sized room in a wooden house temporarily for the use of the school. I have requested the Natives form a committee, and have given them a Māori copy of the Code (16 August, 1883, BAAA 1001/345b).

In a letter to the Department of Education, the teacher at Huria noted that the hapu had its own way of electing a committee and the hapu was keen to maintain their traditional leadership structures (Woller, 2011). However, the school at Huria was quickly and continuously plagued by poor attendance, mostly due to ill health. In 1891, Ngāi Tamarāwaho requested that two small blocks of land of approximately three acres each be returned to them so they could cultivate food for the children attending school in the hope of improving their health (Riseborough, 1999). The request was denied.

The effects of the alienation of ancestral lands continued to impact on Ngāi Tamarāwaho. An ongoing trend of outmigration and poor health affected the ability of the hapu children to attend school, and in August 1893, Inspector of Native Schools, James Pope, recommended that the school be temporarily closed:

At the beginning of May, 18 of the pupils left school to help their parents work in the maize fields at Te Puke. In June, measles came; the disease was very fatal, five deaths of infants resulting. By 24th July three-fourths of the school had left the settlement along with their parents, and by the $9^{\text {th }}$ of August the settlement was almost entirely forsaken. On 14th August there was not a single pupil in attendance. The rain, 
the measles epidemic, and the need for going far away to get food have been temporarily fatal to the school, which should now be closed $(26$ August, 1893, BAAA 1001/255a).

What is evident from this extract is that the loss of their economic base and the search for work away from their homes resulted in Ngāi Tamarāwaho children assisting their parents in generating an income rather than attending school. Moreover, poor living conditions and disease further inhibited the ability of the children to attend school. Trends such as out-migration, poor health, inadequate housing, and insufficient food were also noted in indigenous groups globally, and were a direct result of colonisation, in particular land loss. The school at Huria was re-opened in 1894, and the teacher noted that the children were:

\begin{abstract}
Most wretchedly clad. Their poor rags do not serve for purposes of decency, much less for warmth. It goes to one's heart to see the children shivering on cold mornings, and to hear them crying 'too cold, too cold'. I have to allow them to warm their chilled bodies at the school fire before they can do any work.... The poverty of the Huria Natives is exceptional (Rose, 1997, p. 37).
\end{abstract}

This extract illustrates the extreme poverty of the hapu following the loss of their economic base, and the difficulty the children faced in pursuing an education when their health was so poor. Another request in 1894 for land on which to grow food was denied to the hapu (Riseborough, 1999). In 1895, the teacher at Huria reported that all but three of the school children had been ill with influenza and typhoid fever, and over the following months, there were 14 deaths at Huria, six of them school children. Again, Ngāi Tamarāwaho requested land and again the request was denied. 
The ongoing problems of disease and poor health continued to impact on the ability of the children to attend school and Pope no longer supported the school remaining open.

It seems that the time to close this school has... come. The Natives are thoroughly apathetic and have little intent in the education of their children... thus there is really no prospect of even partial success here and I think the school should be closed (16 May, 1899, BAAA 1001/255a).

The school was permanently closed at the end of June 1900. A request to the Secretary of Education from the hapū to have the school re-opened was declined and, in response to further requests for the school to be re-opened, Pope stated that 'few Māori schools have given us more trouble and less satisfaction' (14 April, 1901, BAAA 1001/255a). Ngāi Tamarāwaho made numerous proposals to the Department of Education that a member of their own hapu be appointed as teacher but they were told that the Department 'could not see its way to accede to their request' (9 April, 1901, BAAA 1001/255a). The issue was closed in November 1901 when tenders were made 'for the removal of the Native School from Judea, near Tauranga and its re-erection... on Motiti Island' (Bay of Plenty Times, n.d.).

Following the closure of the Huria Native School, the hapu was forced to send their children to alternative schools, mostly to Te Wairoa School, Otumoetai School, or Tauranga District School, with Otumoetai School being the preferred option due to its close proximity to Huria (Woller, 2011). Ngatoko (1998, as cited in Woller, 2011) describes his experience at Otumoetai School in the 1930s:

Although we got on well with most of our [Pākehā] schoolmates, we were always aware of the differences between us, that feeling of superiority 
from them, there was always a prejudice.... We slowly got used to their ways, learnt to adjust, it was a case of having to.... [The teachers] taught us all about the British Empire.... It was colonial education and it was drummed in (p. 10).

Thiong'o (1986) argues that for colonisation to be effective, the indigenous culture, including knowledge, must be undermined. Replacing traditional hapū knowledge and histories with that of the Pākehā settlers further enhanced the colonisation of Ngāi Tamarāwaho.

Thiong'o (1986) also argues that language suppression is a necessary step in the colonisation process and that, concomitant with the suppression of culture, is banning the use of indigenous languages. This leads to the re-moulding of the colonised in the image of the coloniser. Along with having to adapt to a new environment, hapu children were also faced with the exclusive use of the English language within the classroom setting. Ngatoko (1998, as cited in Woller, 2011) remembers:

We were not to speak Māori at school. If we were caught we had to stand in front of the class and get the strap. Some of the [Pākehā] kids would tell on us if we spoke Māori; we would be singled out and punished (p. 11).

Atawhai (as cited in Derby, 2016) discusses the suppression of the native language of Ngāi Tamarāwaho:

Our grandparents were not able to speak their own tongue... and what that did was form a lost generation [and] disrupt the intergenerational transfer of knowledge. Now those people have to learn their own language when they are in their ‘60s. 
Poor health continued to plague Ngāi Tamarāwaho. In 1938, Pākehā parents of children at Otumoetai School requested a separate school for hapū children because 'so many native children... frequently arrive wet and suffer constantly from colds' (7 April, 1938, Otumoetai School Committee Book 1927 1940). The parents also cited malnutrition, lice and tuberculosis (Wainwright $\&$ Feint, 2000). Roimata (as cited in Derby, 2016) recalls: 'Having started at Otumoetai, we were transferred to the native school at Bethlehem; I wasn't sure why at the time.' Typhoid remained a problem at Huria until the middle of the $20^{\text {th }}$ century due to the lack of clean water, and access to Tauranga hospital was problematic due to the Health Board's reluctance to treat citizens who did not pay rates (Wainwright \& Feint, 2000). Alfred (2009) cites ill health as a common trend among indigenous peoples, and this trend was evident in Ngāi Tamarāwaho.

Theorists who research the effects of colonisation on the identity of indigenous peoples find that phenomena associated with colonisation have an overwhelming effect on the identities of these groups. Analysis of the colonisation experience of Ngāi Tamarāwaho reveals that the confiscation of their tribal estates led to a breakdown in the traditional structure of the hapū, which affected the ability of members of the hapu to practise traditional cultural customs and speak their language. Wainwright and Feint (2000) argue that groups who lose their land to an alien culture risk losing their identity, and they attribute the change in the identity of Ngāi Tamarāwaho directly to colonisation and, more specifically, to the alienation of tribal lands. The Tauranga District Lands Act 1867 effectively legislated the hapu out of existence, and for decades Ngāi Tamarāwaho was mistakenly referred to as descending from Mataatua waka and belonging to the iwi of Ngāi Te Rangi (Wainwright \& Feint, 2000). For some hapū members, this still occurs today, and Ana (as cited in Derby, 
2016) comments, 'It's so wrong.... We are not Mataatua [or Ngāi Te Rangi] and it belittles our kids'.

\section{THE RESURGENCE OF NGĀI TAMARĀWAHO IDENTITY}

The hapū sent countless petitions to Parliament demanding justice be served for the confiscation of tribal lands and the associated economic, social and cultural effects (Riseborough, 1999). Their first petition was lodged in 1866 requesting the return of their ancestral land, and each subsequent petition reiterated this request. To provide some idea of their industry, Ngāi Tamarāwaho petitioned the Crown in 1866, 1877, 1884, 1907, 1911, 1920, 1922, 1923, 1927, 1937, seven petitions in 1944, several in 1945, 1947, 1948, 1949, 1950 and 1958 (Wainwright \& Feint, 2000). The constant petitioning was a strain on their already limited resources. In order to raise funds, hapu members laboured for local farmers, pulling gorse, digging drains and picking maize, and they donated half of their meagre earnings to whoever was going to Wellington to present their petitions to parliament (Riseborough, 1999).

The notable increase in the number of petitions Ngāi Tamarāwaho filed in the 1920s was driven predominantly by hapū leader, George Hall, and supported by the wider hapū. Hall wrote that unless the historical injustices were righted Ngāi Tamarāwaho would 'remain slaves to their Pākehā brethren for all time' (as cited in Riseborough, 1999, p. 110). He signed the petitions 'on behalf of a people who have been reduced to poverty and whose progress has been retarded by the erroneous confiscation of tribal lands' (p. 116). Responses from Native Ministers and other government officials constantly addressed Ngāi Tamarāwaho as a 'subtribe of Ngaiterangi [and that] practically the whole of the confiscated land belonged to the Ngaiterangi Tribe' (AJHR, 1928, p. 18). Ngāi Tamarāwaho persisted in asserting their identity as a hapu in their own right belonging to the iwi of Ngāti Ranginui, with Hall petitioning for the right to be heard... as distinct 
from, and not under the domination of Ngaiterangi' (as cited in Riseborough, 1999, p. 113). As the Second World War drew to a close, under the leadership of Te Hare Piahana, the hapu again increased the number of petitions they filed, with seven being lodged in 1944 alone (Wainwright \& Feint, 2000).

Despite the lack of progress in having their grievances heard, the decade of the 1950s marked a turning point for Ngāi Tamarāwaho in their quest to cement their identity as a hapu in their own right in Tauranga. By this time, prominent hapū and Māori leader, Dr Maharaia Winiata, ${ }^{2}$ had emerged as an influential figure in Ngāi Tamarāwaho. His education, combined with his traditional Māori upbringing, was invaluable to the hapū. His appointment as a tutor for Māori Adult Education meant he was able to run classes at Huria in 1949 and 1950, and this led to the formation of the Ngāti Ranginui Historical Society, which encouraged people to learn their history and genealogy (Riseborough, 1999). In 1950, with the support of Te Hare Piahana, Winiata established a carving school at Huria and, from this, the Ranginui Academy of Māori Arts and Crafts was formed. Their aim was to build a new wharenui (meeting house) to replace the existing house, which was named Te Kaponga (Tai, as cited in Derby, 2016). This was a deliberate and strategic response to the loss of identity; and the plan to rename the wharenui Tamateapokaiwhenua after the captain of the Tākitimu waka was a conscious assertion of their mana whenua (territorial rights) and belonging in the Tauranga region. The building of the new wharenui was captured by Te Ao Hou:

A new era is dawning for the people of Judea Pa. They are trying by their great undertaking to restore their lost prestige.... This wharenui will

\footnotetext{
${ }^{2}$ For details on the life and achievements of Dr. Maharaia Winiata see http://www.teara.govt.nz/en/biographies/5w41/winiata-maharaia (retrieved 4 October, 2015)
} 
stand as a symbol of progress and great achievement, a memorial to the immortals of the seven canoes, and an appropriate meeting place for future generations' (Te Ao Hou: The New World, 1955, p. 35).

It was opened by King Korokī on 5 May of that year and attended by many tribal groups from all over the country (Bay of Plenty Times, 5 May, 1956). These groups took the opportunity to discuss the land confiscations and, from those discussions, they passed what is now referred to as Resolution One, which reads:

On the occasion of the ceremonial opening of the 'Tamatea-pokai-whenua' ancestral meeting house... this representative gathering of the tribes contemplate with a deep sense of sorrow and regret the prolonged suffering... on account of the confiscation of 54,000 acres of their valuable tribal lands.... Mover: Pei Te Hurinui, Seconder: Tame Reweti' (Souvenir Booklet, 1958, p. 37).

For Ngāi Tamarāwaho, the resolution that was carried unanimously by those present was a public proclamation of their identity, endorsed by King Koroki and recognised by the many tribal groups that came to pay their respects to Ngai Tamarāwaho on that day (P. Winiata, personal communication, 23 March 2013). 'It took Maharaia Winiata and his uncle Te Hare Piahana to bring back the identity of the Ngai Tamarāwaho people by the raising of the [wharenui]' (Mason, 2000, p. 3). The opening of the wharenui had a profound impact on the identity of Ngāi Tamarāwaho, and is viewed as a major turning point in the evolution of the identity of the hapū (Derby, 2016). 


\section{Conclusion}

The exploration of the identity of Ngāi Tamarāwaho in the colonisation era revealed that the socio-historical context of this era played a significant role in influencing the identity of the hapu. More specifically, analysis of the interplay between Ngāi Tamarāwaho and colonisation revealed that phenomena associated with colonisation, and more explicitly phenomena that altered the socio-economic profile of Ngāi Tamarāwaho, had an impact on the identity of the hapū. Comparisions with other indigenous groups globally revealed the hapu possessed a very similar profile to these groups as a result of colonisation; namely, low educational outcomes, poor health, limited access to land, substandard housing and the lack of an economic base. It is necessary to note that while it has often been suggested that colonisation 'happened to' indigenous groups around the world, this notion implies that these groups were powerless, unaware, passive, and lacked an understanding of what was occurring around them. It is therefore, important to stress that while Ngāi Tamarāwaho did not 'invite' many of the phenomena associated with colonisation, such as a low socio economic profile primarily caused by land loss, the hapū did make conscious decisions in response to colonisation that demonstrated, as best as possible in the socio-historical context of this era, their rangatiratanga. Such decisions included the choice by many whānau not to teach their children te reo Māori but, rather, they decided that proficiency in English was a better option for their future; or some hapū members chose to move away from the traditional tribal area of Ngāi Tamarāwaho in the hope of achieving better socio-economic outcomes elsewhere.

The alienation of tribal lands and a trend of out-migration fragmented the hapu and created a diasporic population that resulted in limited opportunities to utilise cultural practices. The identity of the hapu was no longer solely constructed in a single setting, and for some members of Ngāi Tamarāwaho, 
their identity was influenced by varying social norms, particularly if they associated with multiple or hybrid sites of belonging as a result of out-migration. However, evident in research involving hapū members (Derby, 2016) is recognition of the actions of protest and assertion by Ngāi Tamarāwaho at the injustices they faced as a result of colonisation. The hapu gained a sense of pride through the efforts and resilience of those members of Ngāi Tamarāwaho who fought tirelessly to ensure the identity of the hapu was not altered beyond recognition. The building of the wharenui, Tamateapokaiwhenua, played a central role in the assertion of their identity as a hapu, and this contributed to the reassertion and recognition of Ngāi Tamarāwaho as a hapū in its own right following the devastation caused by colonisation. In closing, the constant evolution of Ngāi Tamarāwaho identity in response to the events or nature of different stages of the colonisation era, reveals the salience of socio-historical context to identity, and thus highlights the need for research relating to identity to consider the influence of socio-historical context on the identity of a group. 


\section{References}

\section{Newspapers}

Bay of Plenty Times.

\section{Unpublished Sources}

Moeke-Pickering, T. (1996). Māori Identity Within Whānau: A review of literature. University of Waikato Māori \& Psychology Unit. Unpublished paper. Hamilton: New Zealand.

\section{Online Sources}

Moreton-Robinson, A. (2003). I Still Call Australia Home: Indigenous Belonging and Place in a White Postcolonizing Society. Retrieved 25 August, 2015 from http://is.muni.cz/el/1421/podzim2009/AJ28084/um/M oreton-Robinson.pdf

Te Ao Hou. (1955). Ranginui Academy for Arts and Crafts. Retrieved 8 September, 2015 from http://teaohou.natlib.govt.nz/journals/teaohou/issue/Ma o10TeA/c25.html

\section{Archives}

Appendices to the Journal of the House of Representatives. 1928. Tauranga Public Library.

Māori Schools - Building and Site Files - Huria 1888-1909, BAAA 1001/255a, Archives New Zealand.

Māori Schools - Building and Site Files - Maungatapu School 1881-1888, BAAA 1001/345b, Archives New Zealand.

Otumoetai School Committee Book 1927-1940, Tauranga Public Library.

\section{Ngāi Tamarāwaho Archives}

Mason, T. (2000). Brief of evidence for WAI 659. Tauranga, New Zealand.

Matthews, D. (2000). Brief of evidence for WAI 659. Tauranga, New Zealand. 
Mikaere, B. (2015). Mana o Ngāi Tamarāwaho Incorporated. Tauranga, New Zealand.

Ngatoko, M. (2000). Brief of evidence for WAI 659. Tauranga, New Zealand.

Opening Ceremonies of the Tamateapokaiwhenua Meetinghouse and Iwipupu Dining Hall, 5 May 1956, Souvenir Booklet.

Tata, D. (2000). Brief of evidence for WAI 659. Tauranga, New Zealand.

Winiata, F. (2000). Brief of evidence for WAI 659. Tauranga, New Zealand.

\section{Miscellaneous}

Wainwright, C., \& Feint, K. (2000). Submissions of counsel for Ngāi Tamarāwaho. Wellington, New Zealand: Buddle Findlay Solicitors.

\section{Reports}

Evans, G. M. (1997). Te Whenua o te Kupu Whakaari: Ngāi Tamarāwaho (Report commissioned by the Waitangi Tribunal). Wellington, New Zealand: Waitangi Tribunal.

Nightingale, T. (1996). Re-housing Tauranga Mãori 1935-72 (Report for the Waitangi Tribunal). Wellington, New Zealand: Waitangi Tribunal.

O'Malley, V. (1996). The Te Papa Block: A History of Church Missionary Society and Crown Dealings, 1838-1867 (Report commissioned by the Crown Forestry Rental Trust). Wellington, New Zealand: Crown Forestry Rental Trust.

Riseborough, H. (1999). Ngāi Tamarāwaho: Protectors of the Prophecy (Report commissioned by the Crown Forestry Rental Trust). Wellington, New Zealand: Crown Forestry Rental Trust.

Rose, K. (1997). The Impact of Confiscation: Socio-Economic Conditions of Tauranga Māori, 1865-1965 (Report for Crown Forestry Rental Trust). Wellington, New Zealand: Crown Forestry Rental Trust.

Stokes, E. (1990). Te Raupatu o Tauranga Moana: The Confiscation of Tauranga Lands (Report prepared for the Waitangi Tribunal). Hamilton, New Zealand: University of Waikato. 


\section{Conference Papers}

Woller, P. (2011). Seeking education success while maintaining cultural identity: The intergenerational educational experiences of an extended family. Paper presented at the Emerging Scholars Conference, California.

\section{Theses}

Butcher, E. A. (2012). 'This is my ideal life': the importance of place for how Māori elders understand a good life (Master of Arts thesis). Massey University, New Zealand.

Derby, M. (2016). Te Whanaketanga o Ngāi Tamarāwaho: The evolution of hapu identity (Master of Arts thesis). AUT University, New Zealand.

Houkamau, C. (2006). Identity and socio-historical context: transformations and change among Maori women (Doctoral thesis). University of Auckland, New Zealand.

\section{Journal Articles}

Alfred, G. T. (2009). Colonialism and State Dependency. Journal de la santé autochtone, 5(2), 42-60.

Blash, R., \& Unger, D.G. (1995). Self-concept of African American Male Youth: Self-esteem and Ethnic Identity. Journal of Child and Family Studies, 4(3), 359-373.

Lee, S. J. (1997). The road to college: Hmong women's pursuit of higher education. Harvard Educational Review, 67(4), 803-827.

McCormack, F. (2011). Levels of indigeneity: the Māori and neoliberalism. Journal of the Royal Anthropological Institute, 17(2), 281-300.

Panelli, R., Allen, D., Ellison, B., Kelly, A., John, A. \& Tipa, G. (2008). Beyond Bluff oysters? Place identity and ethnicity in a peripheral coastal setting. Journal of Rural Studies, 24(1), 41-55.

Schulz, A. J. (1998). Navajo Women and the Politics of Identity. Social Problems. 45(3), 336 - 356.

Strauss, A. (1994). Identity, Biography, History and Symbolic Representations. Social Psychology Quarterly. 58(1), 4-12. 


\section{Books}

Binney, J. (1968). The Legacy of Guilt: A Life of Thomas Kendall. Auckland, New Zealand: Oxford University Press.

Ka'ai-Oldman, T. (1988). A History of New Zealand Education from a Māori Perspective. In Hirsh, W. \& Scott, R. (Eds.), Getting It Right - Aspects of Ethnicity and Equity in New Zealand Education (pp. 22-29). Auckland, New Zealand: The Office of Race Relations Conciliator.

Kirmayer, L. J., \& Valaskakis, G. G. (2009). Healing Traditions: The Mental Health of Aboriginal Peoples in Canada. Vancouver, Canada: University of British Columbia Press.

Korgen, K. O. (1998). From Black to Biracial: Transforming Racial Identity among Americans. Connecticut: Praeger.

Labov, W., \& Waletzky, J. (1967). Narrative analysis: Oral versions of personal experience. In J. Helm (Ed.), Essays on the verbal and visual arts. Seattle: University of Washington Press.

Mair, G., \& Gifford, W. H. (1937). The story of Gate Pā, April 29, 1864: supplemented by extracts and other matter and illustrations gathered and compiled from various sources by W. H. Gifford. Tauranga, New Zealand: Bay of Plenty Times.

Mikaere, A. (2011). Colonising Myths Māori Realities. Wellington, New Zealand: Huia Publishers.

Pere, R. (1988). Te Wheke: whaia te māramatanga me te aroha. In S. Middleton (Ed.), Women and education in Aotearoa (pp. 6-19). Sydney, Australia: Allen \& Unwin.

Phinney, J. S. (1993). A three-stage model of ethnic identity development in adolescence. In M. E. Bernal \& G. P. Knight (Eds.), Ethnic identity: Formation and transmission among Hispanics and other minorities (pp. 61-79). New York: State University of New York Press.

Strauss, A. (1959). Mirrors and Masks: The Search for Identity. San Francisco: Sociology Press.

Tajfel, H. \& Turner, J., (1986). The social identity theory of intergroup behaviour. In S. Worchel (Ed.), Psychology of intergroup relations. Chicago: Nelson Hall.

Trask, H. K. (1999). From a Native Daughter: Colonialism and Sovereignty in Hawai'i. Hawai'i: University of Hawai' $i$ Press.

Thiong'o, N. (1986). Decolonising the Mind: The politics of language in African literature. Nairobi: East African Publishers. 
Walker, R. (1989). Māori identity. In D. Novitz \& E. Wilmott. (Eds.) Culture and Identity in New Zealand (pp. 35-52). Wellington, New Zealand: Government Printer.

Walker, R. (1990). Ka Whawhai Tonu Matou: Struggle Without End. Auckland, New Zealand: Penguin.

Ward, A. (1995). A Show of Justice: Racial Amalgamation in Nineteenth Century New Zealand. Auckland, New Zealand: Auckland University Press.

Ward, A. (1999). An Unsettled History: Treaty claims in New Zealand today. Wellington, New Zealand: Bridget Williams Books. 